\title{
Die Suid-Afrikaanse soldaat: 'n historiese profiel
}

\section{Lt kdr EM Meyers*}

This article perceives the South African soldier within a historical framework. Although prominence is given to general traits and characteristics in this historical profile, the role of foreign influences, trends in warfare and the environment is also dealt with. The author postulates the notion that the South African soldier's dynamic development over the past 75 years has to a large extent been influenced by the changing nature of warfare. It is concluded that the modern South African soldier is well-trained, highly motivated and adaptable. Although he has a conservative outlook on military traditions, he displays a flexible and innovative approach to matters such as strategy and tactics.

\section{Inleiding}

Die Suid-Afrikaanse soldaat het oor ' $n$ tydperk van meer as drie eeue ' $n$ evolusie van kompanjiesoldaat en boerepionier deurloop tot by die opgeleide krygsman van vandag wat in konvensionele sowel as onkonvensionele oorlogvoering onderlê is.

Eienskappe soos dapperheid, patriotisme, eie inisiatief, vindingrykheid, individualisme, militêre begrip, ' $n$ individualistiese benadering tot dissipline, 'n liefde vir diere, kennis van die veld, godsdienssin, eie leierskeuse en besluitneming het teen die agtergrond van die Suid-Afrikaanse milieu ontwikkel en loop soos 'n goue draad tot by die soldaat van vandag. In die groeiproses het vreemde invloede (oa vanaf Brittanje en Duitsland) op die Suid-Afrikaanse militêre tradisie ingewerk. Daarby het sy natuurlike omgewing ' $n$ belangrike rol gespeel. ' $n$ Begrip van dié evolusie verg 'n kort perspektief van die SuidAfrikaner se besondere verdedigingsgeskiedenis. Spesiale klem word gelê op die gedrag en eienskappe van die Suid-Afrikaanse soldaat soos dit in krisissituasies na vore kom.

\section{Veeboer-pionier}

'n Mate van selfstandigheid het reeds by die Kaapse vryboere ontwikkel aangesien hul hulself en hul families teen ongediertes en roofsugtige inboorlinge moes beskerm. Tog was dit vir hulle en die latere veeboere nodig om in lewensgevaarlike omstandighede saam te staan en 'n gemeenskaplike bedreiging te trotseer. Tydens die bewind van die Hollands Oos-Indiese Kompanie is al die Kaapse koloniste in ' $n$ burgermag onder beheer van burgeroffisiere georganiseer. ${ }^{1}$

Van Jaarsveld wys daarop dat die burgers nie ' $n$ staande mag gehad het nie en dat die boer desnoods self soldaat was: 'Wij zijn van self Beschermers van onze land en Bewaakers tegen alle invallen van vijanden'. ${ }^{2}$ Die kern van die kommandostelsel wat later tot stand gekom het, was die Boer met sy perd en sy geweer. Die militêre geskiedenis van die veeboer-pionier word gekenmerk deur die beweeglikheid van die berede kommando's. Tog was die kommandostelsel ondoeltreffend vanweë die onvermoë van die meeste burgers om by basiese militêre dissipline aan te pas. ${ }^{3}$ Die voortbestaan van die kommandostelsel is egter gewaarborg deur die oproepstelsel waardeur burgerkommando's saam met Britse eenhede in die grensoorloë van die 19de eeu geveg het. ${ }^{4}$

Oor die algemeen was die burgers bereid om ter wille van selfbehoud diens te verrig andersins nie. Pasifisme onder burgers wat nie op kommando wou gaan nie, is in eie geledere deur die oplegging van 'n geldelike boete gestraf wat vir hulle afwesigheid moes vergoed. ${ }^{5}$

\section{Trekkertydperk}

Hul drang na vryheid en soeke na politieke vryheid het die grensboere eindelik laat besluit om te trek. Op hul trek na die binneland het die Trekkers ' $n$ vorm van die kommandostelsel in hul konfrontasies met die binnelandse stamme gebruik. By die veldslae van Vegkop teen die Matabeles en Bloedrivier teen die Zulus is ' $n$ nuwe verdedigingstelsel, $\mathrm{nl}$ die walaer in gebruik geneem. ${ }^{6}$

Die Kaapse koerante het lede van die Pretorius kommando beskryf as nie alleen mensliewend en godsdienstig nie, maar tewens ruim bedeeld met mannemoed en vaste geloof. Hoewel die Voortrekkers baie van die Zulus moes verduur, was hulle nooit haatdraend of wraaksugtig nie. ${ }^{7}$ 


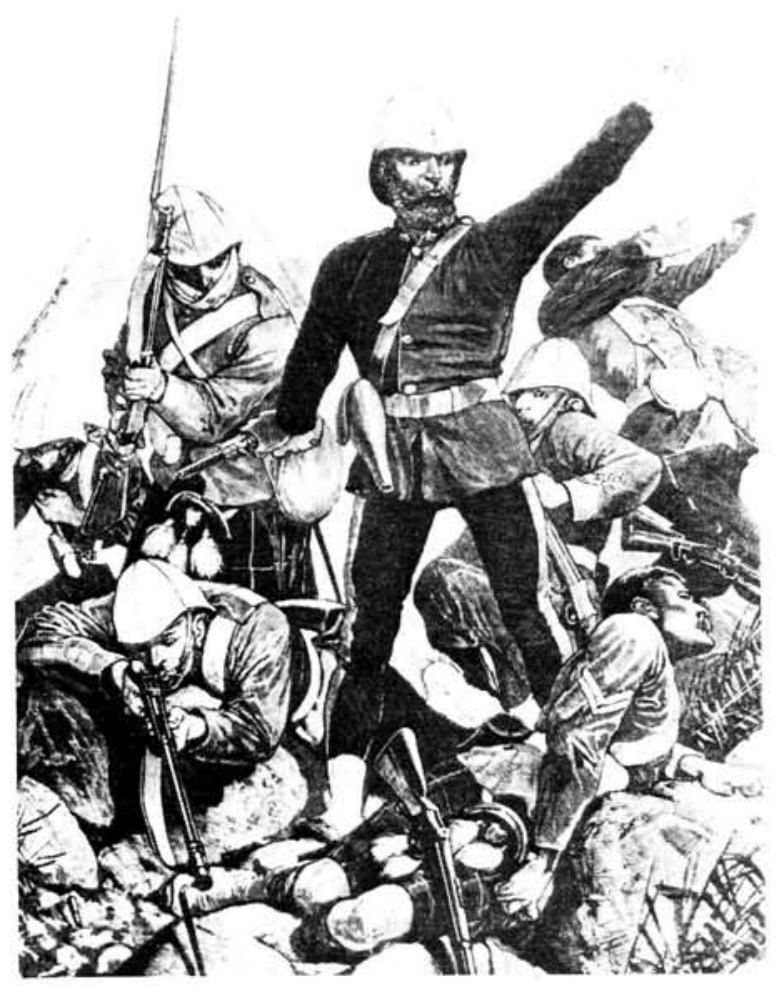

Die Transvaalse Oorlogsgeneraal, Sir Colley by die Slag van Majuba, net voordat hy gesneuwel het
Die Burgermag het bestaan uit alle weerbare manne tussen 16 en 60 jaar en hulle moes opstandige stamme onderdruk. In 1867 het Vrystaters vir die laaste keer na die geweer gegryp in hul stryd teen die Basoeto's om hul grondgebied te beskerm. ${ }^{8}$

Die funksie van die Suid-Afrikaanse soldaat het dus nog nie verander van die dae dat hy aan die Oosgrens as veeboer-pionier sy eie besit en die veiligheid van sy gesin moes beskerm het nie

Die Trekkers is voortgedryf deur ' $n$ allesoorheersende drang om hul duurgekoopte vryheid teen elke prys te behou. Met die anneksasie van die Republiek Natalia het Potgieter persoonlik aan Pretorius beloof dat indien die land verdedig moes word, hy 'zelve prezend zou wees om te helpe streiden' 9

Duxbury loof die Boer vir sy moed om 'n leeu te konfronteer. Dié moed tesame met goeie ruiterskap en skerpskutterskap het hom in staat gestel om die gevare van die Trek te oorleef en hom in die binneland te vestig. ${ }^{10}$

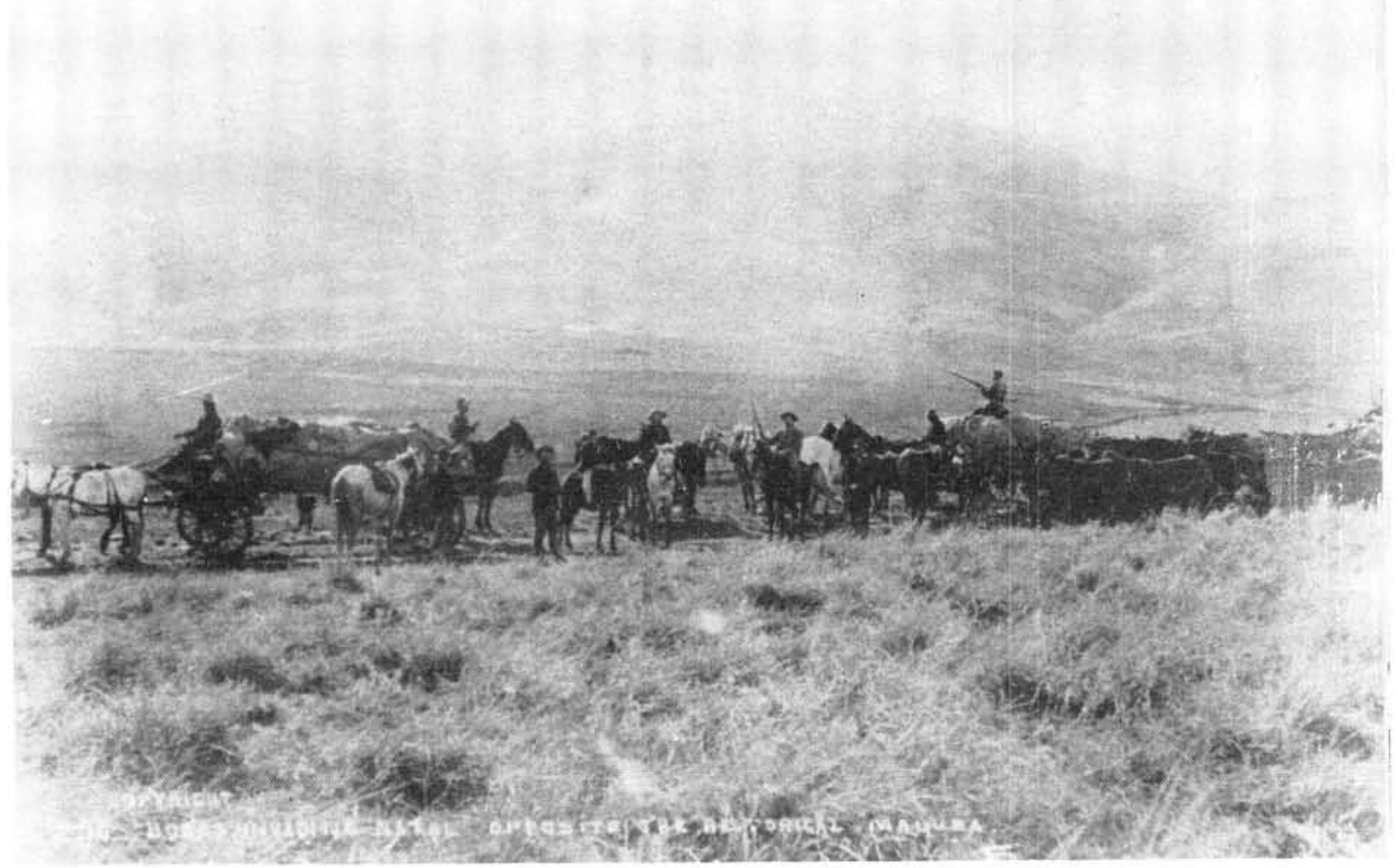

Die Boere trek Natal binne. Boere met wapens, beeste en voorrade aan die oorkant van die historiese Majuba 


\section{Eerste Vryheidsoorlog}

Die Eerste Vryheidsoorlog het die trefkrag van die Boerekommando's teen opgeleide infanteriesoldate beklemtoon. Die Boere was goeie skerpskutters, kon hulle gebiedsvoordeel goed gebruik en het bekwame leiers gehad, aldus geskiedskrywers. ${ }^{11} \mathrm{Na}$ aanleiding van die oorwinning op Majuba van 27 Februarie 1881, wat 'n groot taktiese oorwinning vir die Boere was, lewer Ransford kommentaar op die burgers se besondere militêre vernuf en dapperheid: "Here were a few hundred men prepared to assault a position which any professional soldier of the time would have insisted was impregnable. ${ }^{12}$

Die burgers waarop die Transvaalse Republiek in 1881 staatgemaak het, was meestal boere. Die oop veld was hulle natuurlike tuiste en hulle het leer perdry voor hul sesde jaar en was uitstekende skuts op 10-jarige leeftyd. Die agtervolging van wild was tweede natuur en hulle kon byna net so stil soos skaduwees deur die veld beweeg. Ammunisie was skaars en die gejagte dier moes met die eerste skoot platgetrek word. ${ }^{13}$

Tog was die Boerekrygers nie in die ware sin van die woord soldate nie, aangesien hulle geen pa- radewerk of geweerdril gedoen het nie. Met die uitsondering van die Staatsartillerie het hulle geen uniforms gedra nie, maar was gekleed in gewone plaasdrag met bandoliers oor hul skouers. 'n Gebrek aan dissipline en eiesinnigheid onder die burgers was die grootste probleem waarmee burgeroffisiere te kampe gehad het. ' $n$ Tweede swakheid was dat Boerekrygers altyd weggeskram het van swaar ongevalle en daarom het hulle verkies om in ' $n$ hopelose situasie eerste te onttrek as om in ' $n$ heroïese verdedigingspoging te sterf. ${ }^{14}$

Die Boerekryger se vernaamste wapen was sy Christelike geloof. Verder was die stelsel van 'n volksleër daarvoor verantwoordelik dat die republikeinse regerings met besielde manskappe kon veg. ${ }^{15}$

\section{Tweede Vryheidsoorlog}

Die Tweede Vryheidsoorlog was die grootste kragmeting in die geskiedenis van die Boererepublieke, maar tegelykertyd was dit vir Brittanje die kwaaiste militêre toets in baie jare ${ }^{16}$ Hoewel die Boer geen formele opleiding as berede soldaat gehad het nie, het sy leefwyse as berede skutter die leemte gevul. Die burger op kom-

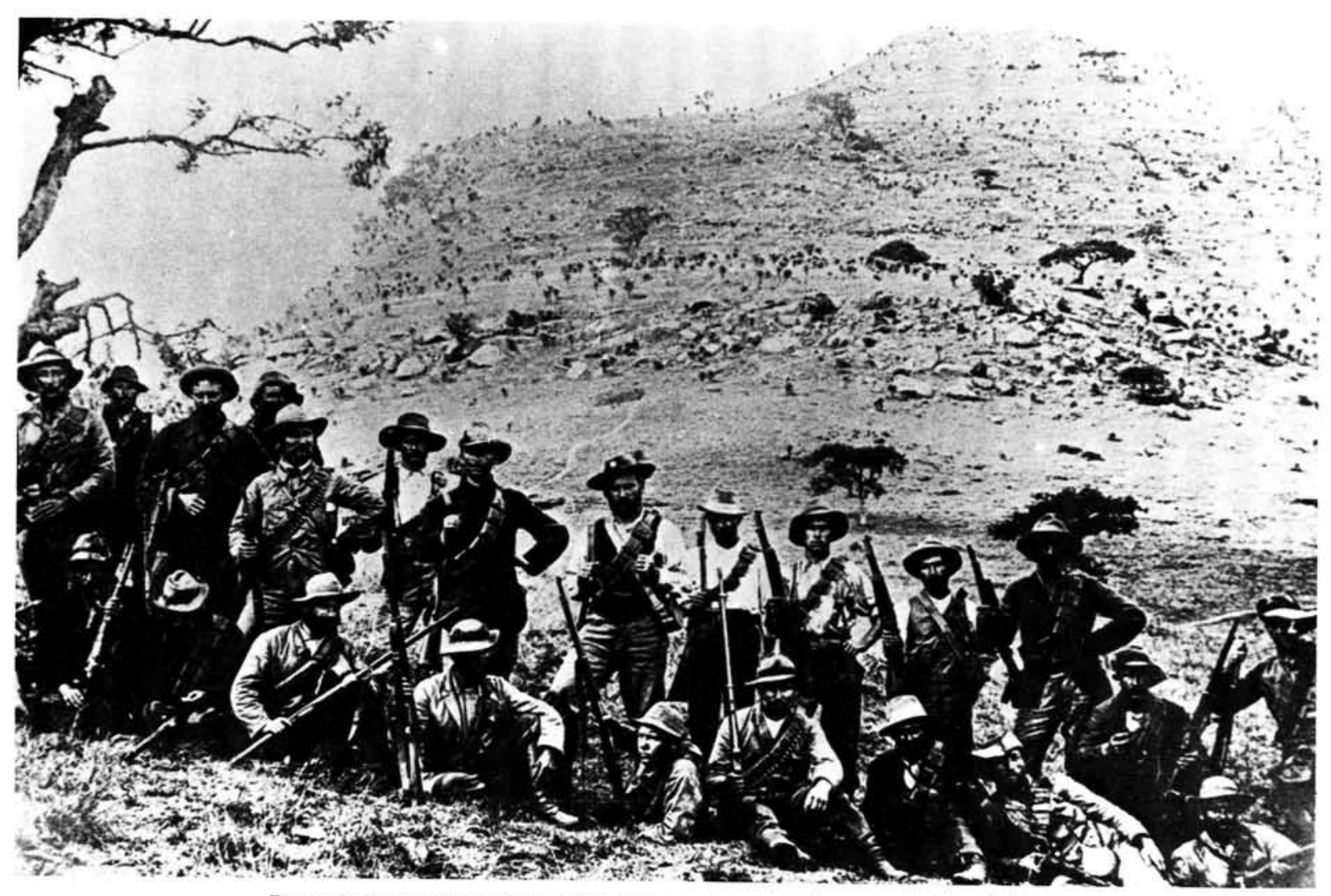

Boere-kommando op Spioenkop poseer in rye met gewere en bandoliers 
mando is nie besoldig nie, gevolglik was hul benadering tot dissipline anders as die wat in Europa op dienspligtiges van toepassing was. Hy was in die eerste instansie 'n patriotiese burger en in die tweede instansie soldaat. ${ }^{17}$

Die aard en omvang van die republikeinse weerstand was vir Genl Buller, sowel as vir Lord Milner 'n ontnugtering. 'n Maand nadat die oorlog uitgebreek het, het Lord Milner gekla: 'The enemy were more numerous, far better armed regards artillery, and much better organized than we had any idea of ... my gloomy view of their power has been surpassed by reality, ${ }^{18}$

Die guerillastryd waarin genl De Wet en genl De la Rey uitgemunt het, sou die oorlog met twee jaar verleng en aan die Britte hul grootste teenslae besorg. ${ }^{19}$ 'n Britste verslaggewer het van De Wet se metodes gesê: 'De Wet's military methods are governed by no calfbound laws and there is no reason why he should not be successful. $^{20}$

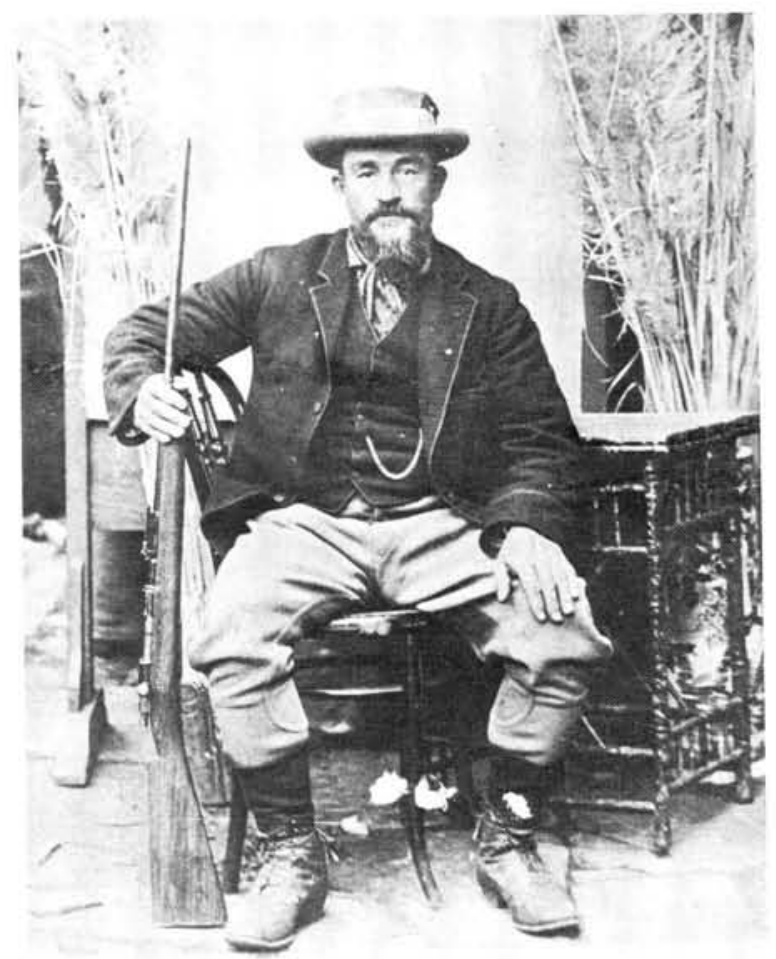

Generaal Christiaan de Wet

Volgens Pakenham het 'n Boerekommando lig en vinnig gereis en van De Wet se kommando sê hy: 'It moved like a hunting cat on the veld'. De Wet se kommando was nie 'n indrukwekkende oorlogsmasjien soos 'n Britse regiment nie, maar desondanks kon dit as effektiewe en aanpasbare gevegselement aangewend word. ${ }^{21}$
Vir die Vrystaters was die enigste uitweg, aldus Churchill, om vegtende onder te gaan. ${ }^{22}$ In die lig hiervan is dit verstaanbaar waarom die Boerekryger die magtige Brittanje vir drie jaar lank so dapper kon weerstaan. Die Boere het 'n nuwe oorlogstaktiek spontaan ontwikkel uit die besef dat hulle nie die manskappe gehad het vir 'n konvensionele stryd nie. Hulle moes die vyand die grootste moontlike verliese toedien en self so min moontlik verliese ly. ${ }^{23}$

$\mathrm{Na}$ die oorlog het Milner die kommandostelsel beëindig wat die kern van die Afrikaner se verdedigingstelsel tot dusver was. In 1912 is 'n Verdedigingswet aangeneem wat voorsiening gemaak het vir 'n klein Staande Mag en Burgermag.

\section{Eerste Wêreldoorlog}

Met die uitbreek van die Eerste Wêreldoorlog in 1914 het die jong Unieverdedigingsmag en daarmee saam die Suid-Afrikaanse soldaat, voor 'n nuwe uitdaging te staan gekom. Vanweë die sterk invloed van 'n Britse militêre tradisie en sy betrokkeneheid in 'n konflik wat wesentlik van die Suid-Afrikaanse tradisie verskil het, het hy hom in 'n nuwe kader bevind. Hy moes aanpas by 'n nuwe stelsel wat besonder formeel was en heelwat dissipline en die erkenning van militêre gesag vereis het. Daarbenewens het verdeelde lojaliteite en die herinnering aan die bittere stryd tussen Boer en Brit sy getrouheid aan die Regering onder groot druk geplaas.

Die Suid-Afrikaanse soldaat het hom as't ware op die kruispad van twee militêre tradisies bevind. Hy het egter getoon dat hy vinnig by 'n vreemde militêre milieu kan aanpas soos dit uit veldslae in Suidwes-Afrika en Frankryk geblyk het.

Die vinnige beweging van die Suid-Afrikaanse soldaat in Suidwes is een van dié veldtog se uitstaande kenmerke. Die Duitsers het dit ongelooflik gevind dat die Suid-Afrikaners sonder aansienlike spoorweghulp so kon vorder, aangesien elke meter van die afstand per voet afgelê is. ${ }^{24}$ Die beweeglikheid van die berede manskappe in Duits Suidwes-Afrika was toe te skryf aan hul ruiterskap, liefde vir diere, die feit dat hulle in staat was om op ' $n$ beperkte kosvoorraad te leef en uitputting te weerstaan. ${ }^{25}$

Die Suid-Afrikaners in Oos-Afrika was meestal jongmanne, burgerlike vrywilligers met skamele opleiding en geen voorkennis van wat op hulle 
gewag het nie. Hulle moes teen 'n goed aangevoerde leër optree wat gewoond was aan bosgevegte en het met onbekende vernietigende tropiese siektes kennis gemaak. Tog het hulle in die stryd volhard. Genl J.C. Smuts het Oos-Afrika as 'n byna bo-menslike vuurproef beskryf en dit op dieselfde vlak as die Groot Trek en die Tweede Vryheidsoorlog gestel. ${ }^{26}$ Genl van Deventer het sy soldate in Oos-Afrika geloof deur te sê dat die manier waarop die troepe die ontberings van die trek deur droë streke sonder water en met min kos verduur het, 'n prestasie is waarop SuidAfrika trots kan wees. ${ }^{27}$

Van die gevegte aan die Wesfront in Frankryk en Vlaandere waaraan die Suid-Afrikaanse Brigade deelgeneem het, staan dié in Delvillebos ongetwyfeld uit in ons militêre geskiedenis, aangesien Suid-Afrikaners ondanks 2815 ongevalle hul stelling in die aangesig van 'n verbete aanslag gehou het.

In 1806 is die Kaapse korps deur Kleurling soldate gestig en met die oorlogverklaring in 1914 is militêre diens uitgebrei om ook Swartes en Indiërs in te sluit. In die Suidwes-Afrika-veldtog is sowat 35000 Swartes, Kleurlinge en Indiërs in 'n nie-vegtende hoedanigheid in diens geneem. Verder het lede van die Kaapse Korps hulself op verskeie geleenthede gedurende die oorlog onderskei. ${ }^{28}$

\section{Tweede Wêreldoorlog}

Met die uitbreek van die Tweede Wêreldoorlog in 1939 het die Suid-Afrikaanse soldaat wat weer eens aan Geallieerde kant geveg het, homself as onverskrokke vegter onderskei. Volgens Moorcraft het die Unie die oorlog met teësinnigheid binnegegaan, maar was in die geveg 'n lojale en bekwame bondgenoot. Suid-Afrika se bydrae vir die Geallieerde saak was 190000 blanke en 60000 nie-blanke soldate sowel as 25000 nieblanke helpers. ${ }^{29}$

Hoewel die Italianers in die Abessiniese veldtog oorweldig is, was dit nie so maklik nie, aangesien die Suid-Afrikaanse Brigade gekonfronteer was met moeilike klimaats- en topografiese toestande in Oos-Afrika. Die Suid-Afrikaners wat volgens genl Wavell 'n deels opgeleide brigade was, moes 200 myl van bykans waterlose en padlose bosagtige woestyn kruis, voordat Italiaans-Oos-Afrika aangeval kon word. ${ }^{30}$

Vergelykenderwys was Suid-Afrikaners, volgens genl-maj Brink swak bevoorraad en gevegsafdelings glad nie goed opgelei nie, en tog het hulle hul goed van hul taak teen die Italianers in Oos-Afrika en Abessinië gekwyt. Wapenhantering en gevegsmetodes was egter vir die SuidAfrikaanse soldaat niks vreemd nie, aangesien hy histories goed daarmee bekend geraak het. ${ }^{31}$

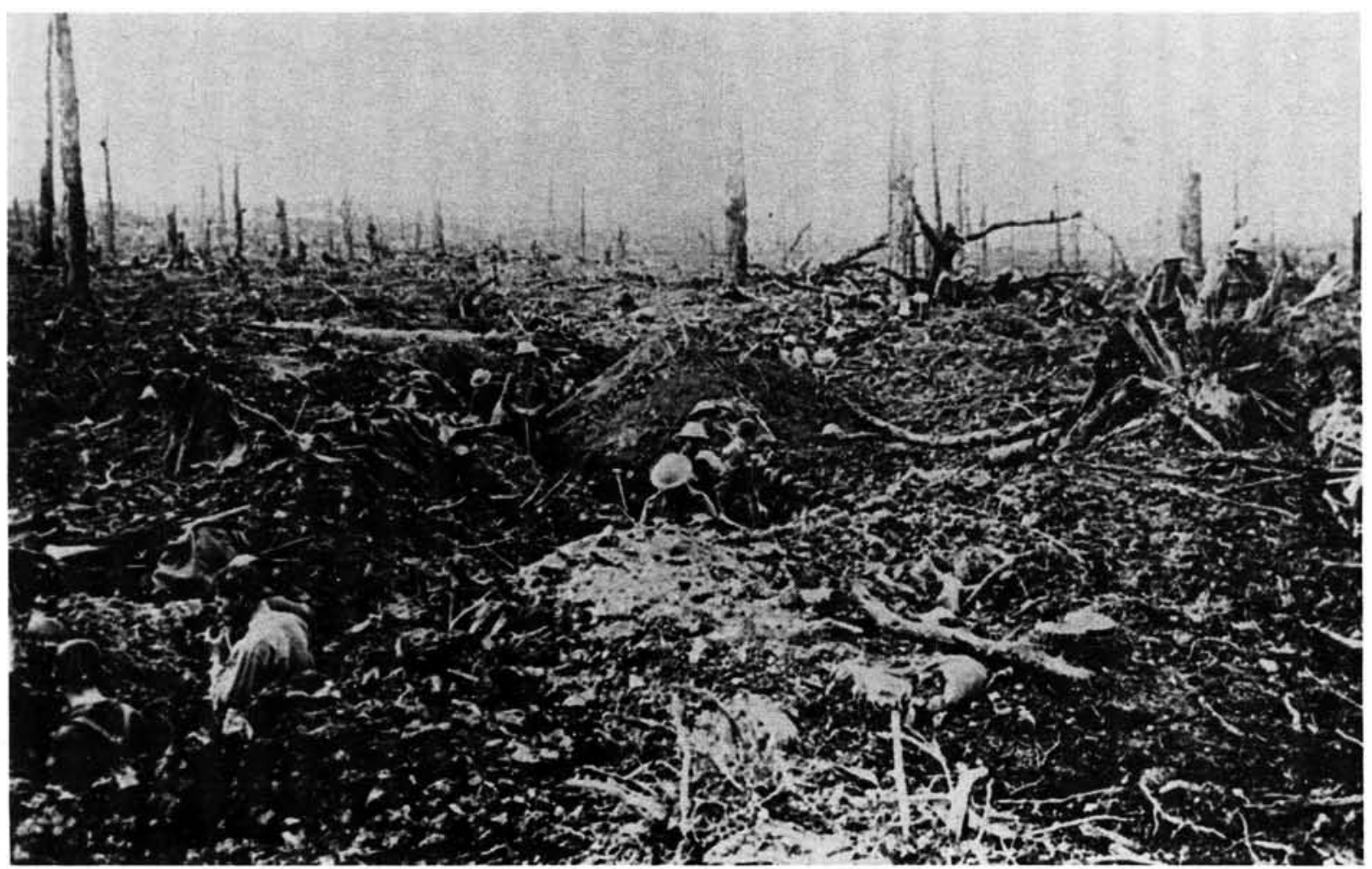

Delvillebos: W01 Soldate in loopgrawe 
Volgens kol Agar Hamilton het Suid-Afrikaners in Italië hulle plek langs die beste Geallieerde troepe ingeneem. Met verwysing na die Duitsers se gedugtheid, het hy die Suid-Afrikaners se dapper optrede geloof: 'Their enemy ... was the most dangerous in the world, but they came with credit through the test' ${ }^{32}$

Van die groot prestasies van die Suid-Afrikaanse sappeurs in Europa, was die voltooiing van twee take wat inderwaarheid op groter vrede en heropbou gerig was. Teen die tyd dat die SA Ingenieurskorps hul hoë vlak brug oor die Porivier voltooi het, het die vyand al oorgegee in Italië en toe die eerste trein oor die herstelde spoor tussen Prato en Bologna geloop het, was die oorlog in Europa verby. ${ }^{33}$ In die elf maande van die begin van Junie 1944 toe die SA sappeurs vir die eerste keer in Rome begin optree het, was hulle alleen verantwoordelik vir die bou van 92 brûe. ${ }^{34}$

Hoewel oorlogsvrees, intense fisiese gevaar en die ongerief van die gevegsituasie verskriklik was, was die kompensasie, aldus Sailor Malan, genoeg om in ruil hiervoor die bevrediging te smaak dat vlieëniers inderwaarheid die enigste mense was wat tussen Hitler en wêreldvryheid gestaan het. ${ }^{35}$

Gedurende die oorlog het Swartes, Kleurlinge en Indiërs in verskeie nie-vegtende hoedanighede soos drywers, baardraers en agterryers gedien. In 1942 is die Indiër Bataljon gevorm wat op dieselfde grondslag as die Kaapse Korps gefunksioneer het. ${ }^{36}$

Hoewel die staandemag aan die begin van die oorlog bitter klein was, is oor die 35000 manne en vroue - Blankes, Swartes en Kleurlinge gewerf om hul plek langs die Geallieerde magte in te neem. Byna almal was vrywilligers. Moorcraft beweer dat Suid-Afrikaners uitstaande soldate was wanneer hulle geveg het - in die verskroeiende hitte van die Noord-Afrika woestyn, tropiese toestande van Madagaskar en ysige berge van Noord-Italie. ${ }^{37}$

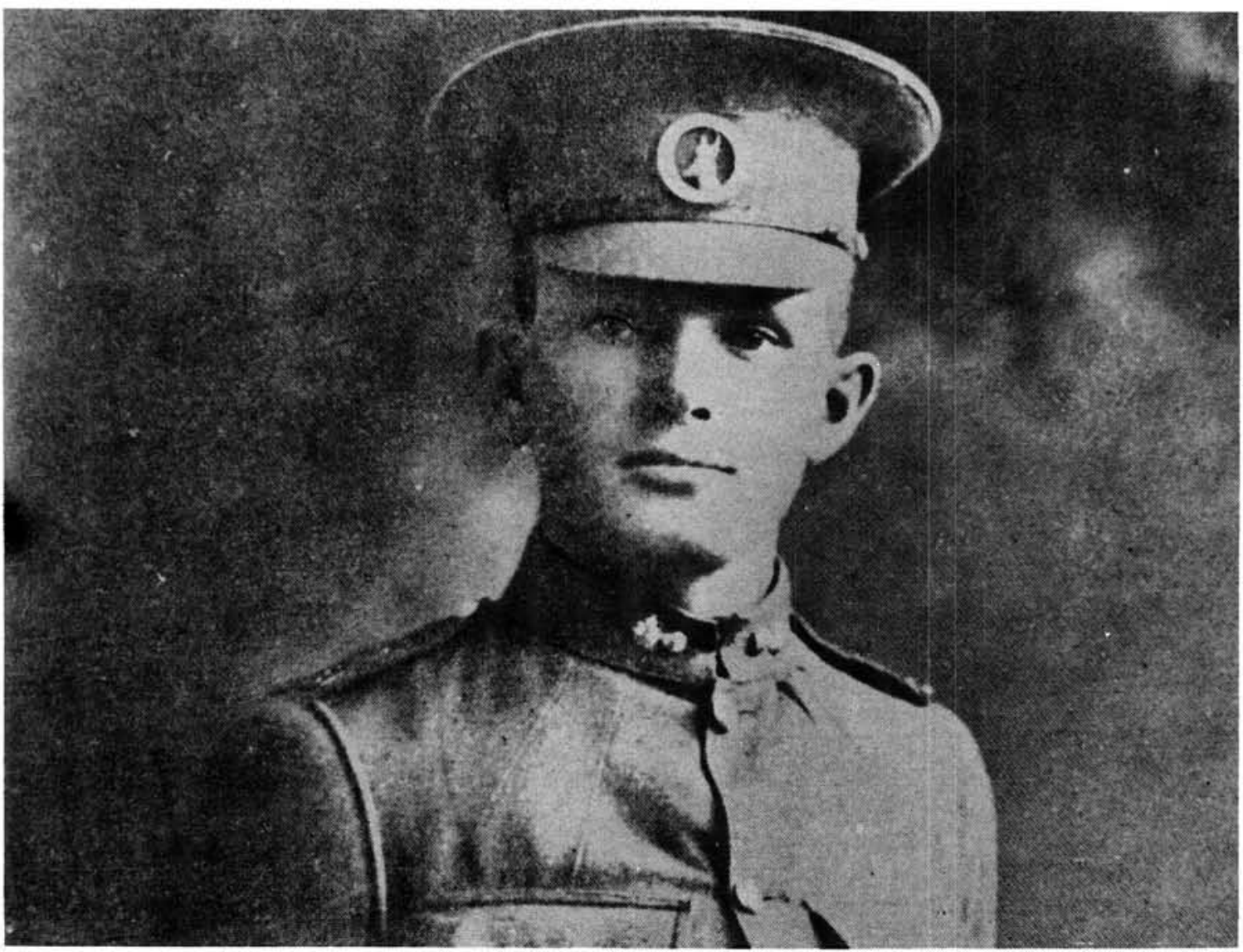

'Go in and shoot their bloody tail feathers out!' Die gunsteling gesegde van generaal Pienaar op die vooraand van 'n slag, is 'n toonbeeld van die vasberadenheid en optimisme waarmee hy die vyand tegemoet gegaan het. Pienaar was egter ook bekend vir sy besondere besorgdheid oor die welsyn van sy manne.

Hierdie eienskap het hom tydens die veldtogte in Abessinië en Noord-Afrika ongewild by sy meerderes gemaak 


\section{Koreaanse Oorlog}

Sedert die Tweede Wêreldoorlog het die SuidAfrikaaanse Lugmag saam met die van die VVOlande in Korea geveg. Sowat 1986 vliegtuie is vernietig in die loop van die Koreaanse oorlog, 'n gemiddelde van 32 per eskader vir 62 eskaders. Hiervan was 79 Mustangs en Sabres, van 2 Eskader en 35 Suid-Afrikaners het in dié oorlog gesterf. ${ }^{38}$

Die gevegsvermoëns van die Suid-Afrikaanse vlieëniers is amptelik deur drie regerings erken naamlik dié van Suid-Afrika, die Verenigde State van Amerika en die Republiek van Korea. Moore wys daarop dat 2 Eskader, nes ander eskaders van die Suid-Afrikaanse Lugmag, besonder aanpasbaar was en ' $n$ vasberadenheid getoon het om sy opdrag uit te voer. ${ }^{39}$

Kol Norman Dodd vertel dat 2 Eskader, oftewel die 'Flying Cheetahs', met soveel dapperheid in Korea geveg het, dat hulle allerweë bewondering afgedwing het. $\mathrm{Na}$ afloop van ' $\mathrm{n}$ besondere waaghalsige missie ter ondersteuning van die grondmagte, het ' $n$ Amerikaanse seesoldaat van hulle gesê: 'The Hall of fame does not possess any greater men than those who flew that day. ${ }^{140}$

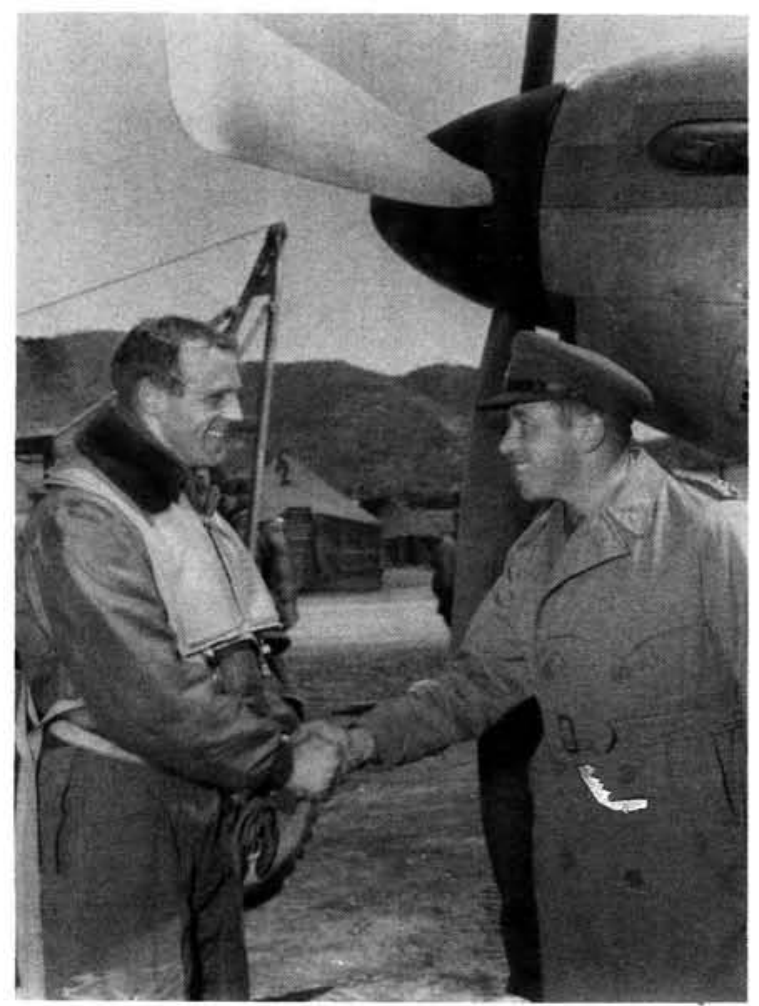

'n Suid-Afrikaanse vlieënier word deur sy maat gegroet voor sy vertrek na Korea

\section{Angolese Burgeroorlog}

In 1975 met die onttrekking van die Portugese leër uit Angola, het 'n magstryd ontstaan tussen drie politieke faksies wat om die oppermag meegeding het en die land is in 'n burgeroorlog gedompel. Die RSA het Angolese ontwikkelings met ontsteltenis waargeneem. ' $n$ Kommunistiese MPLA (Polular Movement for the Liberation of Angola) oorwinning sou onvermydelik tot 'n geïntensifieerde SWAPO aanslag op SWA asook tot destabilisasie van die gematigde regerings van Zambië en Botswana lei. Dit wou Suid-Afrika teen elke prys voorkom. ${ }^{41}$

Die Suid-Afrikaanse taakmag het goed geveg. John Stockwell hoof van die ClA taakmag in Angola, het dit as volg gestel: 'The South African armoured columns teamed with Unita to make the most effective military strike force ever seen in Black Africa, exploding through the MPLA/Cuban ranks in 'n Blitzkrieg which in November almost won the war. ${ }^{142}$

Politieke druk en die versaking deur bondgenote het aan Suid-Afrika geen keuse gelaat as om te onttrek nie.

\section{Suidwes-Afrika}

Die probleem in Suidwes-Afrika is dat die VN die binnelandse partye misken en SWAPO as die enigste verteenwoordiger van die Namibiese volk erken. ${ }^{43} \mathrm{Na}$ die ineenstorting van die Portugese bewind in Angola is die land in ' $n$ toenemende mate as ' $n$ afspringplek vir terroristebedrywighede teen SWA gebruik. Die SA Weermag moes gevolglik ingryp om SWA se belange te beskerm. Na die onttrekking van die SA Magte van die Ruacana/Calueque-waterskema in 1976 het terroriste-aanvalle mekaar meer dikwels op die SWA grens opgevolg. ${ }^{44}$

Verskeie operasies is sedert 1978 deur die SA Veiligheidsmagte op SWAPO-basisse geloods om die plaaslike bevolking te beveilig. Hoewel die SAW gewoond was aan konvensionele oorlogvoering moes hulle nou aanpas by ' $n$ ander soort oorlogvoering naamlik dié van teeninsurgensie operasies. Die teen-SWAPO oorlog in SWA word deur ' $n$ goed gewapende leër wat in nege gebiedskommandemente ingedeel is, gevoer. Uitstaande operasies waarin die SA Weermag teen SWAPO opgetree het, was onder andere dié van Casinga, Protea, Daisy, Smokeshell en Kwiksilwer. 


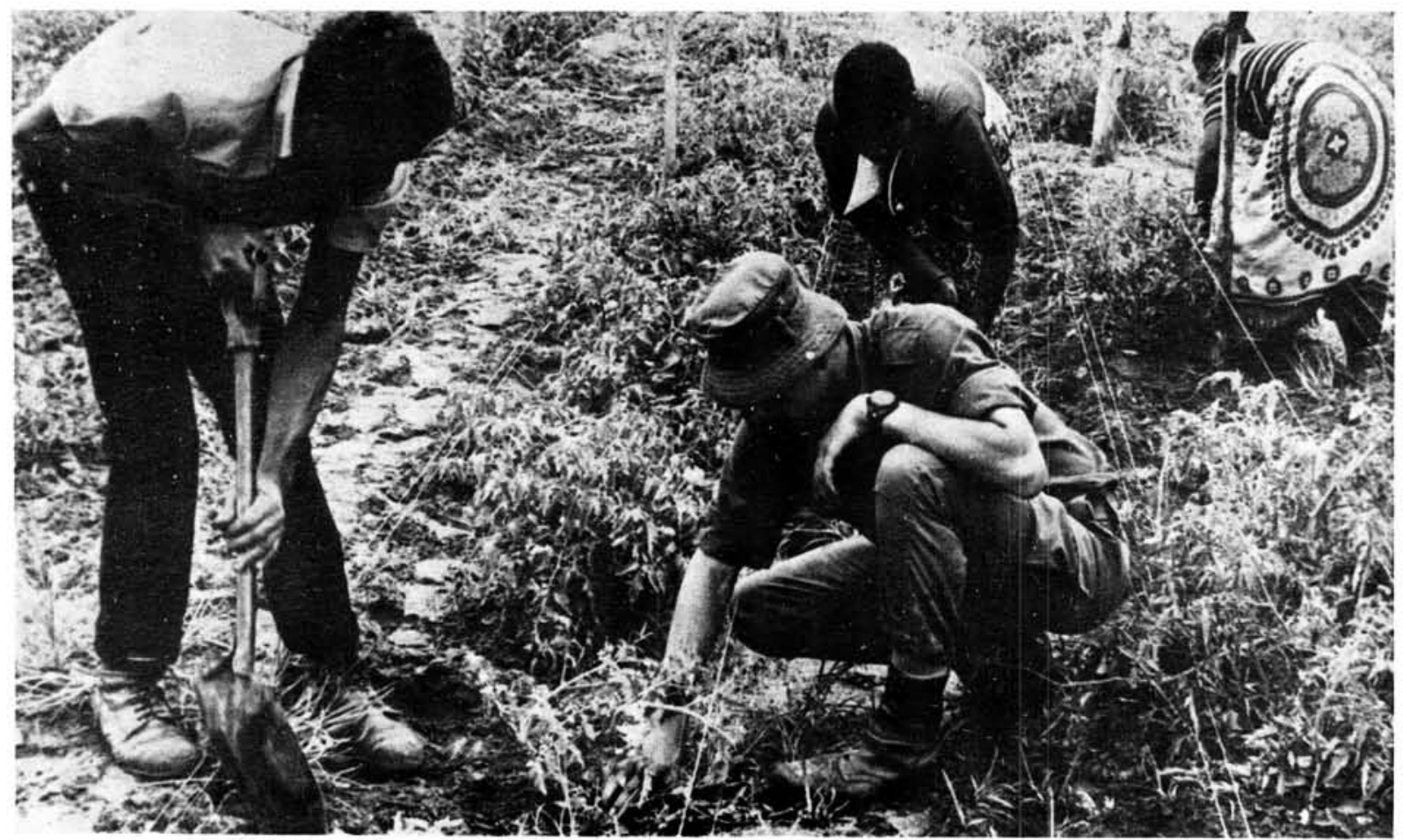

'n Nasionale Dienspligtige van die SAW gee raad aan 'n swart boer in die operasionele gebied terwyl hy die gesaaides inspekteer

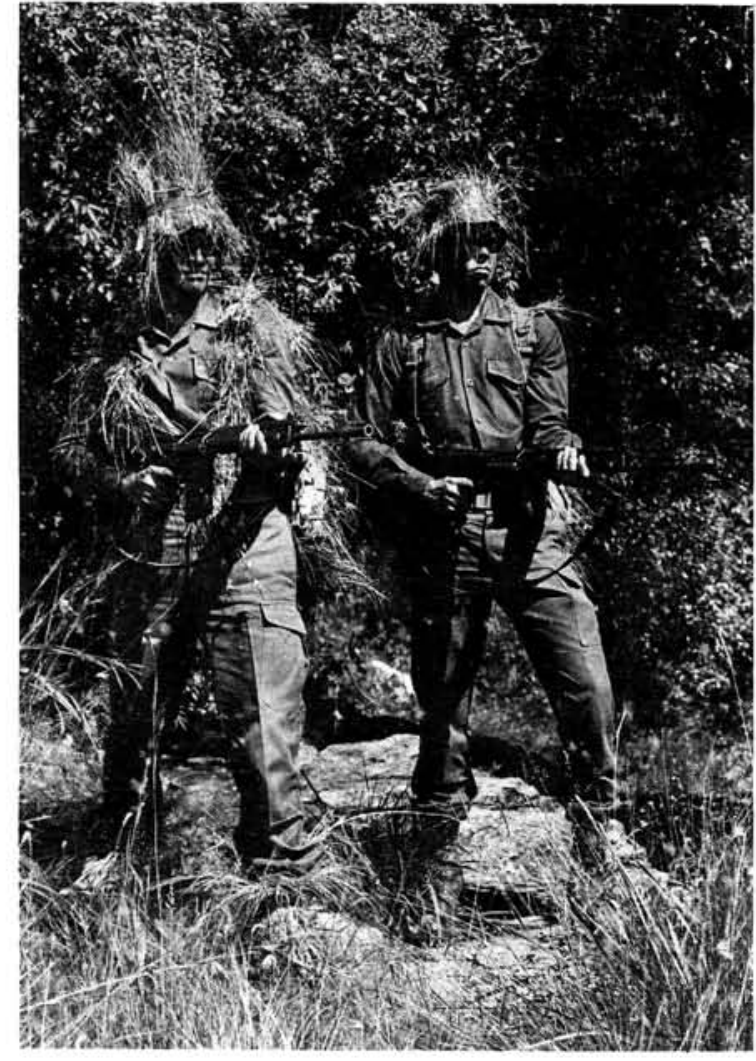

Kennis van veldkuns vorm 'n belangrike deel van die Suid-Afrikaanse soldaat se opleiding
Generaal Walter Walker, internasionale strateeg en voormalige aanvoerder van NAVO in NoordEuropa is van mening dat sou die RSA sy troepe uit SWA onttrek, die vakuum binne 24-uur deur SWAPO gevul sou word. Hy het ' $n$ hoë dunk van die Suid-Afrikaanse soldaat: 'Physically they're as hard as nails. ${ }^{.45}$

Kol Norman Dodd, militêre kenner en skrywer, laat hom as volg oor die Suid-Afrikaanse Weermag, uit: 'Although not large by Western standards the South African Defence Force is a truly national, well trained and well motivated force. ${ }^{146}$

Militêre kenners dwarsoor die wêreld is dit eens dat die Suid-Afrikaanse soldaat feitlik 'n ongeëwenaarde reputasie as vegter het. ${ }^{47}$ In dié verband het genl sir Walter Walker gesê: "Having seen them in action I doubt if such strong men, high leadership and sheer professionalism can be surpassed by other countries in the world today. ${ }^{\prime 48}$

\section{Slot}

Met die hantering van krississituasies oor 'n tydperk van drie eeue het die Suid-Afrikaanse sol- 
date hulself keer op keer bewys as gedugte vegters. Die Kaapse Vryboere moes hulself en hul families teen ongediertes en roofsugtige inboorlinge beskerm. In hul soeke na politieke vryheid het die Trekkers met vyandige binnelandse stamme gebots. Die boerekryger se funksie was steeds, soos in sy dae as veeboerpionier om sy eie besit en die veiligheid van sy gesin te beskerm.

In die twee Vryheidsoorloë het Boerekommando's, gerugsteun deur idealisme en geloof, teen Brittanje te staan gekom in ' $n$ poging om hul republikeinse vryheid te herstel en te behou.

Die Britse oorlogsverklaring in 1914 het die Unie se outomatiese betrokkenheid by die oorlog geïmpliseer en die SA soldaat onder groot druk geplaas. Hy het hom as't ware voor 'n kruispad van twee militêre tradisies bevind. In die Tweede Wêreldoorlog het die Suid-Afrikaanse soldaat weer aan die Geallieerde kant geveg en homself as onverskrokke vegter onderskei.

Meer resent en nader aan ons grense was die Angolese Burgeroorlog waarin die RSA se militêre betrokkenheid die beskerming by Calueque-waterskema en die beskerming van vlugtelingkampe in Angola behels het. Die soort oorlogvoering waarin die SAW in Suidwes-Afrika gewikkel is, wyk heeltemal af van die konvensionele en is ingestel op teeninsurgensie operasies teen SWAPO magte.

'n Nuwe politieke en grondwetlike bedeling is besig om in die RSA gerealiseer te word en binnekort sal die Kleurlinge en Indiërs inspraak in die land se hoogste wetgewende gesag hê. In die uitvoering van hierdie denke is die SAW met sy beleid van multi-etnisiteit die grootste saambindende element van die SA gemeenskap. 'n Feit wat selfs deur die vyande van die RSA erken word. Om hierdie rede is die SAW ' $n$ belangrike teiken vir bomaanvalle deur ANC-gesinde elemente.

Tog is die soldaat van vandag veel beter daaraan toe as die boerekryger van 1899 , aangesien sy uitrusting en wapentuig van die beste is; hy ontvang baie goeie operasionele opleiding; beskik oor beter leiers wat opleiding, kennis en ondervinding betref; sy diensvoordele is beter as die van die boerevegters wat nie eers besoldig was nie en sy eie wapens, ammunisie en proviand slagveld toe moes neem.
Probleme dié het die SA soldaat nog altyd gehad. Oor 'n tydperk van drie eeue het hulle met verskillende vyande te doen gehad onder andere geslepe Hottentotte, onsigbare Boesmans, doodsveragtende impi's, die Britte, die Duitsers en nou - terroriste! Met so 'n trotse krygsverlede is daar vir die Suid-Afrikaanse soldaat geen ander uitweg as om die kontemporêre vyand, die terroris, met hand en tand te beveg nie.

* Lt kdr EM Meyers MA (HOD) is verbonde aan die Militêre Informasieburo, SAW

\section{Verwysings}

1. Wichmann, F.A.F., 'Die Wordingsgeskiedenis van die Zuid-Afrikaansche Republiek 1838-1860', Akademiese Proefskrif, Universiteit van Pretoria, Argiefjaarboek vir die Suid-Atrikaanse Geskiedenis, Vierde Jaargang - Deel II, pp 1, 2; Sesa, vol 7. 1972, p. 396

2. Van Jaarsveld, F.A., 'Die Veldkornet en sy aandeel in die Opbou van die Suid-Afrikaanse Republiek tot 1870', MA-Tesis, (1946) Universiteit van Pretoria, Argiefjaarboek vir die Suid-Atrikaanse Geskiedenis, Dertiende Jaargang - Deel II, p. 226; Sesa. 0p. cit., p. 399

3. Curson, H.H., 'The Pre-Union Forces of the Transvaal 1852-1910' 1950, p. 32

4. Sesa, op. cit., p. 398

5. Van Jaarsveld, op. cit., p. 237; Curson, op. cit., p. 30

6. Stander, H., Die Verhouding tussen die Boere en Zoeloe tot die dood van Mpande in 1872; Akademiese proefskrif, (1963). Universiteit van Pretoria, Argiefjaarboek vir Suid-Afrikaanse Geskiedenis, Sewe-en-twintigste Jaargang - Deel II, p. 236; Sesa, op. cit., p. 399

7. Stander, $O p$. cit., p. 237; Preller, G.S., Andries Pretorius Lewensbeskrywing van die Voortrekker Kommandant-generaal' Bloemtontein, 1940, p. 125

8. Grobbelaar, J.J.G, 'Die Vrystaatse Republiek en die Basoetoe-Vraagstuk', Akademiese proefskrit, Universiteit van Stellenbosch. Argiefjaarboek vir die Suid-Afrikaanse Geskiedenis, Tweede Jaargang - Deel II, pp 164, 165; Sesa. op. cit., pp 399, 400

9. Wichmann, op. cit., p. 32

10. Duxbury, G.R. et al. (reds), 'Eerste Vryheidsoorlog 1880-1881 Honderjarige Uitgawe, Krygshistoriese Tydskrif, Deel 5, nr 2, Des 1980, p. 45; Van Jaarsveld, F.A. et al., (reds) 'Die Eerste Vryheidsoorlog', Pretoria. 1980 , p. 178

11. Bouch, R.J., Infanterie in Suid-Afrika' Dokumentasiediens SAW, Pretoria, 1977, p. 23; Sesa, op. cit., p. 399

13. Pakenham, Thomas, 'The Boer War', London and Sydney, 1982 p. 109; Duxbury, op. cit., p. 44

14. Pakenham, op. cit., p. 109

15. Ibid, p. 110; Du Preez, Sophia 'Vredespogings gedurende die AngloBoere-oorlog tot Maart 1901', MA-tesis, (1976) Universiteit van Pretoria, p. 56; Pakenham, op. cit., p. 105

16. Sesa op. cit., p. 402

17. Du Preez, op. cit., p.31; Bouch, op. cit., pp 29, 30

18. Du Preez, op. cit., p. 26

19. Meiring, Piet, Jan Smuts die Afrikaner, Tafelberg 1974, p. 45

20. Du Preez, op. cit., p. 103

21. Pakenham, op cit., p. 331

22. Churchill, Winston Spencer, 'lan Hamilton's March', London 1900, p. 228

23. . Du Preez, op. cit., p. 105

24. Collyer, J.J., 'The Campaign in German South West Africa 1914-1915' Pretoria 1937, p. 153

25. Ibid, p. 173

26. Collyer, J.J., 'The South Africans with General Smuts in East Africa 1916', Pretoria, 1939, pp. vii, ix

27. Ibid, p. 192

28. Nöthling, C.J., 'Blacks, Coloureds and Indians in the SA Defence Force' South African International, Vol II No. 1. July 1980, p. 23

29. Moorcraft, P.L., 'Africa's Super Power', Sygma/Collins, 1981, p. 15

30. Orpen, Neil, 'East African and Abyssinian Campaigns', South African Forces World War II Vol 1, Cape Town, p. 55 
31. Bouch, op. cit., p. 147

32. Goetzsche, Eric 'Rough but Ready', An official history of the Natal Mounted Rifles an its antecedent and associated units 1854. 1969, 1971, p. 274

33. Orpen, Neil and Martin, H.J., 'Salute the Sappers', South AFrican Forces World War II, Vol VIII, Johannesburg, 1982 p. 317

34. Ibid, p. 325

35. Walker, Oliver, 'Sailor Malan', London, 1953, p. 90

36. Nöthling, op. cit., p. 23

37. Moorcraft, op. cit., p. 15

38. Moore, D.M., 'The Role of the South African Air Force in the Korean War 1950-1953'. Akademiese proetskrit, (1982), Universiteit van SuidAtrika. p. 439
39. Ibid, pp 440,445

41. Dodd, Norman L., 'South Africa the Half-Way House of the World' Army Quarterly and Defence Journal, vol 7, 1975 p. 318

41. Moorecraft, op. cit., p. 34

42. Ibid, p. 39

43. Moorecraft, op. cit., p. 44

44. The History of the South African Defence Force, Dokumentasiediens, pp 10,11

45. 'Russians are waging war - General Walker', Cape Times 25.10.1977; 'Lightning raid praised. Attack is best defence - former NATO chief', Pretoria News, 16.5. 1978

46. Dodd, Norman L., 'South Africa - 1979', Defence, June 1979, p. 466

47. 'Oud-Hoof van NAVO prys SA soldate' Hootstad, 15.10.1977

48. Toespraak van die Staatspresident, 15.10.1983 